\title{
Animal keeping in Chalcolithic north-central Anatolia: what can stable isotope analysis add?
}

\author{
Catriona Pickard $^{1}$ (D) - Ulf-Dietrich Schoop ${ }^{1} \cdot$ László Bartosiewicz $^{2} \cdot$ Rosalind Gillis $^{3}$ • \\ Kerry L Sayle ${ }^{4}$
}

Received: 29 March 2016 / Accepted: 8 September 2016 / Published online: 30 September 2016

(C) The Author(s) 2016. This article is published with open access at Springerlink.com

\begin{abstract}
Stable isotope analysis is an essential investigative technique, complementary to more traditional zooarchaeological approaches to elucidating animal keeping practices. Carbon $\left({ }^{13} \mathrm{C}\right)$ and nitrogen $\left(\delta^{15} \mathrm{~N}\right)$ stable isotope values of 132 domesticates (cattle, caprines and pigs) were evaluated to investigate one aspect of animal keeping, animal forage, at the Late Chalcolithic (mid-fourth millennium BC) site of Çamlıbel Tarlası, which is located in north-central Anatolia. The analyses indicated that all of the domesticates had diets based predominantly on $\mathrm{C}_{3}$ plants. Pig and caprine $\delta^{13} \mathrm{C}$ and $\delta^{15} \mathrm{~N}$ values were found to be statistically indistinguishable. However, cattle exhibited distinctive stable isotope values and, therefore, differences in diet from both pigs and caprines at Çamlıbel Tarlası. This difference may relate to the distinct patterns of foraging behaviour exhibited by the domesticates. Alternatively, this diversity may result from the use of different grazing areas or from the foddering practices of the Çamlıbel Tarlası inhabitants.
\end{abstract}

Catriona Pickard

Catriona.Pickard@ed.ac.uk

1 School of History, Classics and Archaeology, University of Edinburgh, William Robertson Wing, Old Medical Quad, Teviot Place, Edinburgh EH8 9AG, UK

2 Osteoarchaeological Research Laboratory, Department of Archaeology and Classical Studies, Stockholm University, Wallenberglaboratoriet, 10691 Stockholm, Sweden

3 UMR 7209: Archéozoologie, Archéobotanique: Sociétés, Pratiques et Environnement, Département Ecologie et Gestion de la Biodiversité, Muséum national d'Histoire naturelle/CNRS (InEE), 55 rue Buffon, 75005 Paris, France

4 Scottish Universities Environmental Research Centre, Rankine Avenue, Scottish Enterprise Technology Park, East Kilbride G75 0QF, UK
Keywords North-central Anatolia $\cdot$ Animal forage $\cdot$ Stable isotope analysis $\cdot \delta^{13} \mathrm{C} \cdot \delta^{15} \mathrm{~N}$

\section{Introduction}

Archaeological research in north-central Anatolia has focused predominantly on Late Bronze Age and Iron Age urban sites. By comparison, prehistoric settlement in the region has received relatively little attention (e.g. Parzinger 1993; Steadman 1995; Özdoğan 1996; Schoop 2005; Düring 2008). As a result, the animal keeping practices and human use of meat and secondary products of this region and time period are poorly understood.

Dietary stable isotope studies of animal bones offer a direct means of reconstructing at least one aspect of animal production: the type of forage domesticates had access to or were given. While such information will not be a panacea in understanding herding practices per se, it elucidates a new dimension directly relevant to animal keeping in the Anatolian region. Here carbon $\left(\delta^{13} \mathrm{C}\right)$ and nitrogen $\left(\delta^{15} \mathrm{~N}\right)$ stable isotope analyses of remains from domesticated animals and humans (Pickard et al. 2016) from the Late Chalcolithic settlement site of Çamlıbel Tarlasi are used to investigate animal diets. The implications of the results for stock-keeping and the consumption of meat and secondary products by a rural farming community in north-central Anatolia are explored.

\section{Çamlıbel Tarlası—archaeological background}

Çamlıbel Tarlası is one of only a very small number of prehistoric sites to have been investigated in north-central Anatolia. Located $2.5 \mathrm{~km}$ east of the modern village of 
Boğazkale (the location of the Late Bronze Age Hittite capital Hattuša), the site was excavated, as a cooperative project between the German Archaeological Institute and Edinburgh University, over three seasons from 2007 to 2009 (Schoop 2010, 2011, 2015 for summary reports). A small, short-lived settlement and mortuary site, Çamlıbel Tarlası was occupied in the mid-fourth millennium BC (Schoop et al. 2009). The site is located on a small plateau (c. $1040 \mathrm{~m}$ asl) in a mountainous and previously wooded region (Dörfler et al. 2000; Marsh 2010), a short distance from the main Budaközü Plain (Fig. 1).

Seven phases of activity (summarised in Table 1) have been identified at Çamlıbel Tarlası, all of which date to the Late Chalcolithic between 3650 and 3375 cal BC. Extractive metallurgy and small-scale agriculture are the principal activities evident at the site. The site's occupants may have been attracted to this location because, in addition to the close proximity of an outcrop of copper ore $\sim 2 \mathrm{~km}$ to the east of the site, the surrounding plateaus would have been ideally suited to small-scale agriculture (Marsh 2010).

\section{Camlıbel Tarlası-the animal remains}

An assemblage of 2752 identifiable animal bones $(67.7 \mathrm{~kg})$ was recovered at Çamlıbel Tarlası (Bartosiewicz and Gillis 2011; Bartosiewicz et al. 2013). Wild species constituted less than $1 \%$ of the assemblage by NISP (Fig. 2). The remains were predominantly waste from food consumption. Cattle dominated the domesticate remains with pig and caprines also common. Tooth wear and epiphyseal fusion data indicate that the vast majority of the cattle were mature animals. Longevity is attributable to several factors in cattle including the slow reproduction rate and intrinsically high value of individuals as well as secondary product exploitation. Single purpose pigs were slaughtered at or before adulthood for meat. The proportion of bones from young to mature caprines was low. In addition to cattle potentially having been used for traction and sheep for wool, all bovids (including goats) were likely exploited for dairy produce. Distinction between the bones of young lambs and kids, however, tends to be unreliable, further distorting

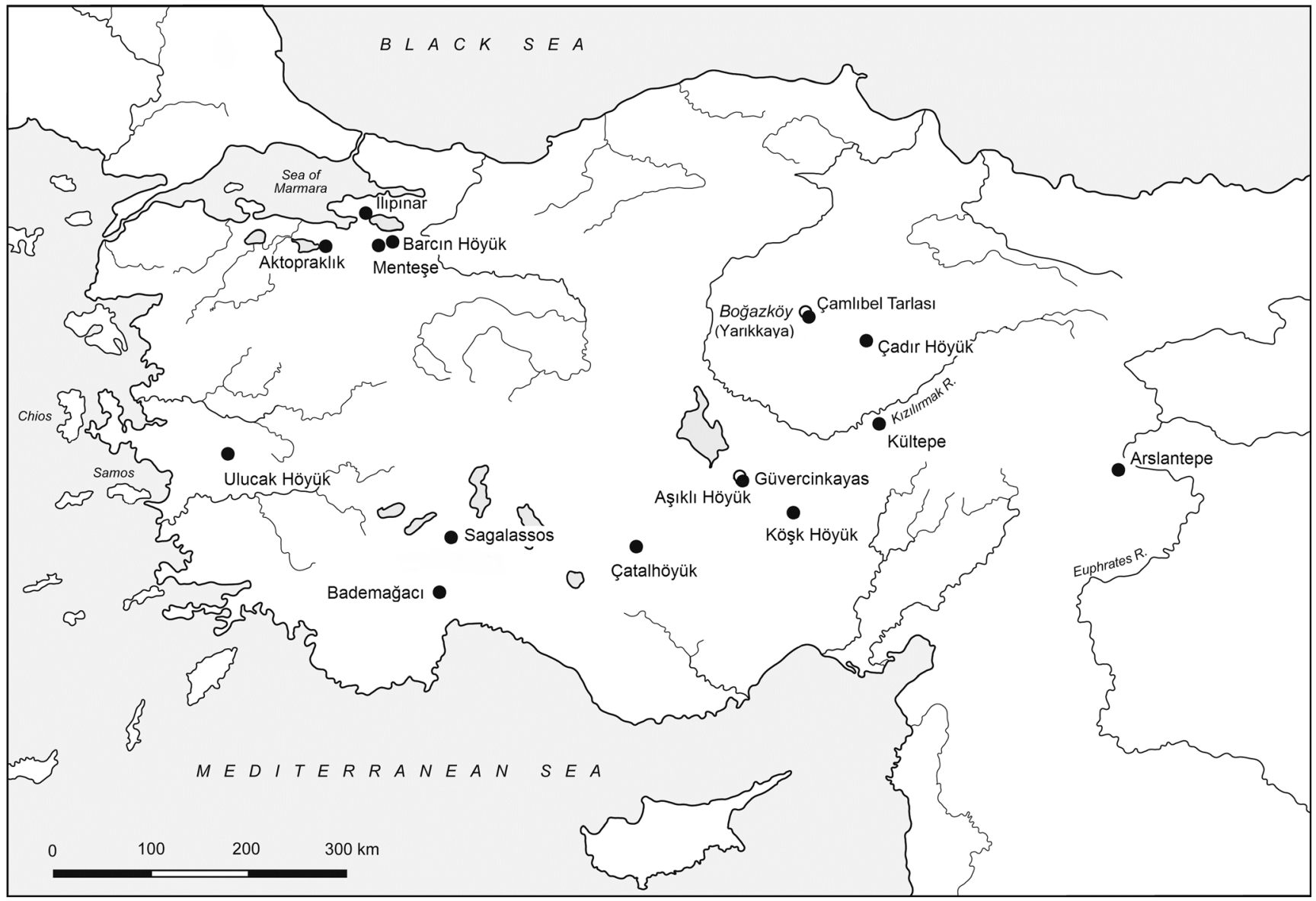

Fig. 1 Map of Anatolia indicating the location of Çamlıbel Tarlası and other major Neolithic and Chalcolithic settlements 
Table 1 Phases of activity at Çamlıbel Tarlası

\begin{tabular}{ll}
\hline Phase & Characteristic features \\
\hline TPEU & Fragmentary burials in plough zone \\
ÇBT IV & Habitations, large courtyard with evidence of slag processing, slag, crucibles \\
SPEU & Second phase of ephemeral use: seasonal presence, bowl furnaces, ore \\
ÇBT III & Large, free-standing buildings, crucibles, copper slag \\
FPEU & First phase of ephemeral use: seasonal presence, bowl furnaces, ore \\
ÇBT II & Dense architecture, room clusters, bowl furnaces, copper ore, many infant graves \\
ÇBT I & No habitation structures, water course, seasonal use?, bowl furnaces, copper ore \\
Virgin soil/bedrock & \\
\hline
\end{tabular}

speculations concerning the 'management' of caprine herds (Bartosiewicz et al. 2013).

It has been inferred from remains of churns found at Çamlıbel Tarlası (Fig. 3) and nearby sites such as Yarkkaya (Boğazköy) that dairy produce was important at least in the local economy (Sauter et al. 2003, Figs. 1, 2 and 3). This is congruent with the identification of animal fats, in one case likely milk fat or a derivative, on two pottery sherds from Yarıkkaya (Sauter et al. 2003).

\section{Problems with proxies}

Animal remains recovered at settlements such as Çamlıbel Tarlasi typically represent food refuse or manufacturing waste unless interpreted as 'ritual' deposits of intact or articulated skeletons. However, there is a tendency to contextualize them in broader terms, inseparably mixing evidence of consumption with far less tangible aspects of exploitation, especially for secondary products. Evidence for the latter is related to animal longevity as secondary products are renewable resources from live animals (e.g. Gerritsen et al. 2010). However, interpretations regarding the bones of calves or lambs/kids alternate between showing emphasis on milk or

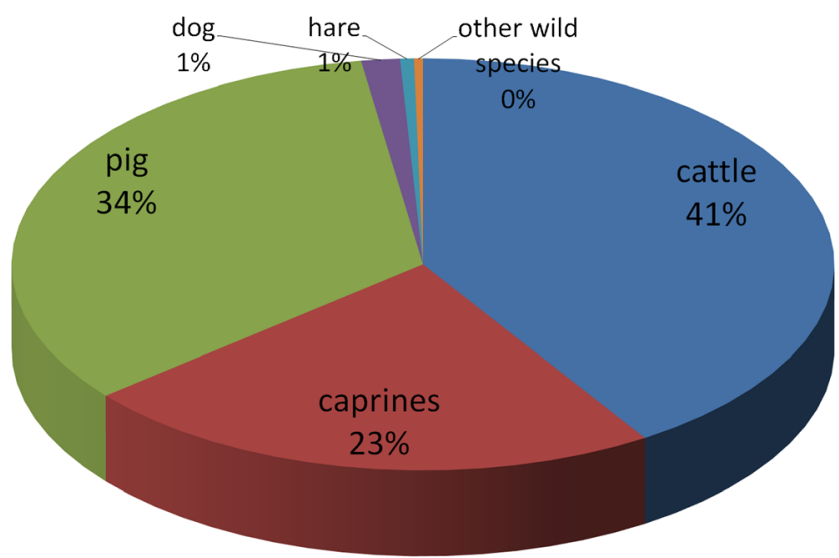

Fig. 2 Animal taxa representation at Çamlıbel Tarlası by NISP meat 'production' (cf. Gourichon and Helmer 2008 and Gerritsen et al. 2010). Moreover, age profiles treated as key evidence are often based on small or unknown numbers of ageable elements encountered among the food remains.

\section{Stable isotope analysis}

Stable carbon and nitrogen isotope analysis of bone collagen has been widely demonstrated to be a useful tool in the investigation of animal diets (e.g. Pearson et al. 2007; Towers et al. 2011; Fuller et al. 2012; Gillis et al. 2013).

The technique involves the measurement of carbon $\left(\delta^{13} \mathrm{C}={ }^{12} \mathrm{C} /{ }^{13} \mathrm{C}\right)$ and nitrogen $\left(\delta^{15} \mathrm{~N}^{14} \mathrm{~N} /{ }^{15} \mathrm{~N}\right)$ isotope ratios in samples of bone collagen (Sealy et al. 1995). ${ }^{12} \mathrm{C} /{ }^{13} \mathrm{C}$ isotopes are incorporated into plant tissues during photosynthesis. Carbon



Fig. 3 Example of a reconstructed pottery 'churn' from Çamlıbel Tarlası II 
isotope ratios $\left(\delta^{13} \mathrm{C}\right)$ vary between plants depending on the mechanism used to fix atmospheric carbon. Most plants fix carbon through one of two routes, either the $\mathrm{C}_{3}$ or $\mathrm{C}_{4}$ pathways (Edwards and Walker 1983). $C_{3}$ plants comprise cereals such as wheat and barley, and most fruits and vegetables, while $\mathrm{C}_{4}$ plants include some tropical grasses and cereals such as millet and sorghum. Variation in plant $\delta^{13} \mathrm{C}$ is passed on to the tissues of animal and human consumers. Plant $\delta^{13} \mathrm{C}$ values may also exhibit inter-species variation within a $\mathrm{C}_{3}$ plant environment (e.g. Feranec 2007). The $\delta^{13} \mathrm{C}$ value of animal bone collagen can therefore be used to determine not only the relative importance of $\mathrm{C}_{3}$ vs $\mathrm{C}_{4}$ plants to diet but may also distinguish between different patterns of foraging behaviour in regions with an exclusively $\mathrm{C}_{3}$ biome (DeNiro and Epstein 1978; Feranec 2007).

Nitrogen isotope ratios $\left(\delta^{15} \mathrm{~N}\right)$ exhibit a 'trophic level' effect, becoming more 'enriched' with each step in the food chain, i.e. they indicate an organism's position in the food chain. The increase in $\delta^{15} \mathrm{~N}$ values of animals over that of their diets has been observed to be in the order of 3-5\%o (e.g. Bocherens and Drucker 2003) - although the diet-consumer offset may vary between species and has been demonstrated to be higher than $5 \%$ in humans (Hedges and Reynard 2007; O'Connell et al. 2012). ${ }^{14} \mathrm{~N} /{ }^{15} \mathrm{~N}$ isotopes may be incorporated into plants from soils and/or drawn from atmospheric $\mathrm{N}_{2}$. Plants that fix nitrogen from the atmosphere (e.g. legumes) generally have lower $\delta^{15} \mathrm{~N}$ values than those plants that fix nitrogen from soil nitrate or ammonium (DeNiro and Epstein 1981). Plant $\delta^{15} \mathrm{~N}$ values can also vary significantly depending on water stress (e.g. Ambrose 1991), salinity (e.g. Britton et al. 2008) and increased nitrogen cycling in forested environments (e.g. van der Merwe and Medina 1991). The variability in $\delta^{15} \mathrm{~N}$ values is passed on to the consumers of plants and may therefore indicate distinctive foraging behaviours among domesticates.

Although the fundamental principles of stable isotope analysis were established in the 1970s and have remained largely unchallenged, it is important to bear in mind that there are a number of additional issues (both dietary and non-dietary) that have implications for the reconstruction of animal forage from stable isotope values, for example the potential effects of physiological stresses, such as gestation and lactation on intra- and inter-individual isotope signatures, as well as the impact of practices such as manuring on isotopic signatures in plants and their animal consumers (e.g. Jenkins et al. 2001; Fuller et al. 2005; Bogaard et al. 2007; Nitsch et al. 2010; Olsen et al. 2014).

\section{Materials and method}

A total of 163 domesticated animal (cattle, caprine and pig) bone specimens from Camlıbel Tarlası were measured for $\delta^{13} \mathrm{C}$ and $\delta^{15} \mathrm{~N}$ to investigate animal forage and human diets (see Pickard et al. 2016) in Late Chalcolithic north-central Anatolia - see Table 2 for animal data.

A sample of approximately $1 \mathrm{~g}$ of bone was taken from each specimen. Pre-treatment included cleaning to remove 1-2 mm of the outer surface of the bone. Collagen was extracted using a modified version of the Longin (1971) method (Brown et al. 1988). Each sample was demineralized in $1 \mathrm{~N} \mathrm{HCl}$ at $20^{\circ} \mathrm{C}$ for a minimum of $24 \mathrm{~h}$, rinsed three times in Milli-Q ${ }^{\mathrm{TM}}$ purified water and gelatinized in $0.03 \mathrm{~N} \mathrm{HCl}$ at $80^{\circ} \mathrm{C}$ for approximately $16 \mathrm{~h}$. The resulting solution was then lyophilised. Samples with well-preserved collagen, i.e. collagen wt $\%$ yield of $>1.00 \%$ (Brock et al. 2010; van Klinken 1999), were measured for $\delta^{13} \mathrm{C}$ and $\delta^{15} \mathrm{~N}$ by the SUERC Radiocarbon Laboratory in East Kilbride, UK, using a Thermo Scientific Delta V Advantage continuous-flow isotope ratio mass spectrometer (CF-IRMS) coupled via a Thermo Scientific ConfloIV to a Costech ECS 4010 elemental analyser (EA) fitted with a pneumatic autosampler. In-house gelatine standards, which are calibrated to the International Atomic Energy Agency (IAEA) reference materials USGS40 (L-glutamic acid, $\delta^{13} \mathrm{C}_{\mathrm{V} \text { - }}$ PDB $=-26.39 \%$ ), USGS41 (L-glutamic acid, $\delta^{13} \mathrm{C}_{\mathrm{V}-\mathrm{PDB}}=+$ $37.63 \%$ ), IAEA-CH-6 (sucrose, $\delta^{13} \mathrm{C}_{\mathrm{V}-\mathrm{PDB}}=-10.45 \%$ ) USGS25 (ammonium sulphate, $\delta^{15} \mathrm{~N}_{\mathrm{AIR}}=-30.41 \%$ ), IAEA-N-1 (ammonium sulphate, $\delta^{15} \mathrm{~N}_{\mathrm{AIR}}=+0.43 \%$ ) and IAEA-N-2 (ammonium sulphate, $\delta^{15} \mathrm{~N}_{\mathrm{AIR}}=+20.41 \%$ ), are run in duplicate for every ten unknown samples. Results are corrected for linearity and instrumental drift and are reported as per mil $(\%)$ relative to the internationally accepted standards VPDB and AIR, with $1 \sigma$ precisions of \pm 0.2 and $\pm 0.3 \%$ for $\delta^{13} \mathrm{C}$ and $\delta^{15} \mathrm{~N}$, respectively. Collagen integrity was assessed according to the following criteria: (i) $\mathrm{C} / \mathrm{N}$ ratio in the range 2.9 to 3.6 (DeNiro 1985) and (ii) minimum $\% \mathrm{C}$ and $\% \mathrm{~N}$ as outlined by Ambrose (1990).

Less than $1 \%$ collagen yield was obtained from 22 samples (seven caprines, 11 cattle and four pig). A further nine samples (one cattle, seven pig and one sheep) had a collagen yield of wt $\%>1.0 \%$ but when measured failed to meet the criteria cited for well-preserved collagen. These samples were excluded from the discussion below.

\section{Results}

The average carbon isotope values of the domesticates (cattle, caprines and pigs) are typical of animals foraging predominantly on $\mathrm{C}_{3}$ resources.

The domestic caprine $\delta^{13} \mathrm{C}$ and $\delta^{15} \mathrm{~N}$ values were found to be relatively homogeneous, with average $\delta^{13} \mathrm{C}=-19.2 \pm 0.5 \%$ and $\delta^{15} \mathrm{~N}=6.4 \pm 0.7 \%$ o $(n=38)$, and are typical of herbivores consuming exclusively $\mathrm{C}_{3}$ resources (cf. Pearson et al. 2007). Little difference in the average isotope values of goat and sheep is evident (sheep average $\delta^{13} \mathrm{C}=-19.1 \pm 0.5 \%$ and 
Table 2 Stable isotope data and collagen preservation indicators of Çamlıbel Tarlası domesticate remains (previously published in Pickard et al. 2016)

\begin{tabular}{|c|c|c|c|c|c|c|c|}
\hline $\begin{array}{l}\text { Sample ID } \\
\text { (GUsi) }\end{array}$ & Species & Phase & $\delta^{13} \mathrm{C}$ & $\delta^{15} \mathrm{~N}$ & $\mathrm{C} / \mathrm{N}$ & $\% \mathrm{~N}$ & $\% \mathrm{C}$ \\
\hline 2202 & Cattle (Bos) & ÇBT III & -19.4 & 5.9 & 3.1 & 13.8 & 37.1 \\
\hline 2205 & Cattle (Bos) & FPEU & -19.6 & 6.0 & 3.2 & 14.6 & 39.9 \\
\hline 2207 & Cattle (Bos) & ÇBT III & -19.4 & 8.0 & 3.2 & 13.3 & 35.9 \\
\hline 2270 & Cattle (Bos) & ÇBT III & -18.1 & 6.2 & 3.2 & 13.6 & 37.7 \\
\hline 2271 & Cattle (Bos) & ÇBT IV & -18.9 & 7.7 & 3.2 & 14.8 & 40.7 \\
\hline 2272 & Cattle (Bos) & ÇBT III & -17.6 & 9.8 & 3.2 & 14.2 & 39.1 \\
\hline 2273 & Cattle (Bos) & ÇBT IV & -19.0 & 8.1 & 3.2 & 14.3 & 39.8 \\
\hline 2274 & Cattle (Bos) & ÇBT II & -19.4 & 9.7 & 3.2 & 13.3 & 36.7 \\
\hline 2275 & Cattle (Bos) & ÇBT I & -16.8 & 7.0 & 3.2 & 12.1 & 33.6 \\
\hline 2276 & Cattle (Bos) & ÇBT I & -18.3 & 6.1 & 3.2 & 13.7 & 37.5 \\
\hline 2326 & Cattle (Bos) & ÇBT II & -19.4 & 6.7 & 3.2 & 13.3 & 36.9 \\
\hline 2327 & Cattle (Bos) & ÇBT I & -18.2 & 6.8 & 3.3 & 15.6 & 43.9 \\
\hline 2328 & Cattle (Bos) & ÇBT III & -20.1 & 7.0 & 3.2 & 13.6 & 37.4 \\
\hline 2329 & Cattle (Bos) & ÇBT I & -19.9 & 6.1 & 3.2 & 15.8 & 43.9 \\
\hline 2330 & Cattle (Bos) & ÇBT II & -19.5 & 8.6 & 3.3 & 14.1 & 39.5 \\
\hline 2331 & Cattle $(B o s)$ & ÇBT I & -18.7 & 6.5 & 3.3 & 15.6 & 43.4 \\
\hline 2332 & Cattle (Bos) & ÇBT I & -18.3 & 6.7 & 3.3 & 15.4 & 43.4 \\
\hline 2333 & Cattle (Bos) & ÇBT IV & -18.8 & 6.3 & 3.2 & 12.4 & 34.1 \\
\hline 2334 & Cattle (Bos) & ÇBT II & -17.4 & 8.9 & 3.3 & 14.9 & 41.6 \\
\hline 2335 & Cattle (Bos) & ÇBT IV & -18.2 & 9.1 & 3.2 & 14.7 & 40.8 \\
\hline 3096 & Cattle (Bos) & SPEU & -19.6 & 6.4 & 3.3 & 11.4 & 31.8 \\
\hline 3114 & Cattle (Bos) & FPEU & -18.5 & 5.5 & 3.2 & 11.3 & 31.4 \\
\hline 3115 & Cattle (Bos) & ÇBT I & -17.0 & 7.5 & 3.2 & 11.8 & 32.6 \\
\hline 3116 & Cattle (Bos) & ÇBT IV & -17.5 & 7.4 & 3.3 & 10.7 & 30.1 \\
\hline 3117 & Cattle (Bos) & ÇBT III/IV & -20.1 & 7.4 & 3.3 & 13.0 & 36.7 \\
\hline 3118 & Cattle (Bos) & ÇBT III & -17.6 & 7.4 & 3.2 & 14.2 & 39.4 \\
\hline 3119 & Cattle (Bos) & ÇBT I & -17.6 & 6.5 & 3.3 & 13.8 & 38.9 \\
\hline 3120 & Cattle (Bos) & ÇBT II & -19.7 & 7.3 & 3.3 & 13.7 & 38.6 \\
\hline 3135 & Cattle (Bos) & ÇBT I & -18.8 & 6.8 & 3.3 & 12.7 & 36.3 \\
\hline 3136 & Cattle (Bos) & ÇBT III & -19.3 & 6.2 & 3.3 & 13.1 & 37.0 \\
\hline 3137 & Cattle (Bos) & ÇBT III & -18.4 & 6.5 & 3.3 & 10.3 & 29.2 \\
\hline 3143 & Cattle (Bos) & ÇBT I & -18.2 & 6.9 & 3.2 & 13.6 & 37.5 \\
\hline 3144 & Cattle (Bos) & ÇBT IV & -18.3 & 6.3 & 3.2 & 12.4 & 34.3 \\
\hline 3145 & Cattle (Bos) & SPEU & -19.2 & 7.5 & 3.2 & 14.3 & 39.7 \\
\hline 3147 & Cattle (Bos) & FPEU & -17.7 & 6.8 & 3.2 & 12.3 & 34.2 \\
\hline 3149 & Cattle (Bos) & SPEU & -18.1 & 8.2 & 3.3 & 10.6 & 29.8 \\
\hline 3154 & Cattle (Bos) & SPEU & -19.2 & 5.9 & 3.2 & 13.1 & 36.2 \\
\hline 3155 & Cattle (Bos) & SPEU & -19.5 & 6.0 & 3.3 & 11.6 & 32.4 \\
\hline 3156 & Cattle (Bos) & FPEU & -19.8 & 7.1 & 3.2 & 11.7 & 32.4 \\
\hline 3157 & Cattle (Bos) & ÇBT I & -20.0 & 6.1 & 3.2 & 12.4 & 34.3 \\
\hline 2325 & Caprine & ÇBT III & -19.2 & 6.5 & 3.2 & 14.8 & 41.3 \\
\hline 3017 & Caprine & ÇBT IV & -18.6 & 7.9 & 3.2 & 12.7 & 35.2 \\
\hline 3022 & Caprine & ÇBT I & -19.6 & 7.3 & 3.3 & 14.5 & 40.3 \\
\hline 3023 & Caprine & ÇBT II & -19.4 & 6.6 & 3.3 & 12.4 & 34.6 \\
\hline 3092 & Caprine & ÇBT III & -19.5 & 7.2 & 3.2 & 13.2 & 36.7 \\
\hline 3254 & Caprine & ÇBT I & -19.4 & 6.1 & 3.2 & 13.2 & 36.8 \\
\hline 3255 & Caprine & ÇBT II & -19.9 & 5.5 & 3.3 & 5.0 & 14.2 \\
\hline 3256 & Caprine & ÇBT I & -19.3 & 6.1 & 3.2 & 13.2 & 36.4 \\
\hline 3257 & Caprine & ÇBT II/III & -19.4 & 7.2 & 3.2 & 13.1 & 36.2 \\
\hline
\end{tabular}


Table 2 (continued)

\begin{tabular}{|c|c|c|c|c|c|c|c|}
\hline $\begin{array}{l}\text { Sample ID } \\
\text { (GUsi) }\end{array}$ & Species & Phase & $\delta^{13} \mathrm{C}$ & $\delta^{15} \mathrm{~N}$ & $\mathrm{C} / \mathrm{N}$ & $\% \mathrm{~N}$ & $\% \mathrm{C}$ \\
\hline 3258 & Caprine & ÇBT III/IV & -19.6 & 7.2 & 3.3 & 7.2 & 24.1 \\
\hline 3259 & Caprine & ÇBT III & -18.8 & 6.2 & 3.2 & 14.3 & 39.6 \\
\hline 3090 & Goat (Capra hircus) & SPEU & -20.2 & 4.9 & 3.3 & 15.3 & 43.1 \\
\hline 3161 & Goat (Capra hircus) & ÇBT IV & -18.0 & 6.0 & 3.2 & 13.4 & 37.2 \\
\hline 3164 & Goat (Capra hircus) & ÇBT III & -19.3 & 5.1 & 3.2 & 10.6 & 29.1 \\
\hline 3168 & Goat (Capra hircus) & SPEU & -19.6 & 6.5 & 3.2 & 8.9 & 24.8 \\
\hline 2204 & Sheep (Ovis aries) & ÇBT I & -18.8 & 5.7 & 3.2 & 12.0 & 32.5 \\
\hline 2268 & Sheep (Ovis aries) & ÇBT III & -19.4 & 7.8 & 3.3 & 13.7 & 38.2 \\
\hline 3018 & Sheep (Ovis aries) & ÇBT IV & -19.7 & 5.4 & 3.3 & 12.1 & 34.0 \\
\hline 3019 & Sheep (Ovis aries) & ÇBT I & -19.0 & 6.2 & 3.3 & 15.5 & 43.4 \\
\hline 3020 & Sheep (Ovis aries) & FPEU & -19.2 & 7.1 & 3.2 & 13.9 & 38.4 \\
\hline 3021 & Sheep (Ovis aries) & ÇBT III & -19.6 & 6.4 & 3.3 & 7.6 & 21.8 \\
\hline 3024 & Sheep (Ovis aries) & ÇBT I & -18.1 & 6.7 & 3.2 & 13.7 & 38.0 \\
\hline 3025 & Sheep (Ovis aries) & ÇBT III & -19.2 & 7.0 & 3.3 & 13.5 & 37.6 \\
\hline 3026 & Sheep (Ovis aries) & ÇBT I & -19.0 & 6.1 & 3.2 & 14.7 & 40.6 \\
\hline 3027 & Sheep (Ovis aries) & ÇBT II & -19.3 & 6.1 & 3.2 & 13.4 & 36.9 \\
\hline 3089 & Sheep (Ovis aries) & ÇBT III & -19.2 & 6.4 & 3.2 & 15.6 & 43.2 \\
\hline 3091 & Sheep (Ovis aries) & SPEU & -18.7 & 6.6 & 3.3 & 11.0 & 30.7 \\
\hline 3093 & Sheep (Ovis aries) & ÇBT III & -19.6 & 7.1 & 3.2 & 14.6 & 40.4 \\
\hline 3094 & Sheep (Ovis aries) & ÇBT IV & -19.0 & 6.2 & 3.2 & 13.1 & 36.3 \\
\hline 3095 & Sheep (Ovis aries) & ÇBT IV & -19.1 & 6.0 & 3.2 & 13.6 & 37.7 \\
\hline 3097 & Sheep (Ovis aries) & SPEU & -20.2 & 5.6 & 3.2 & 14.6 & 40.6 \\
\hline 3098 & Sheep (Ovis aries) & FPEU & -19.3 & 6.5 & 3.3 & 7.7 & 21.9 \\
\hline 3158 & Sheep (Ovis aries) & ÇBT II & -19.5 & 5.9 & 3.3 & 13.9 & 38.8 \\
\hline 3163 & Sheep (Ovis aries) & FPEU & -18.2 & 5.9 & 3.2 & 13.5 & 36.9 \\
\hline 3250 & Sheep (Ovis aries) & ÇBT I & -18.8 & 7.1 & 3.3 & 14.6 & 40.9 \\
\hline 3252 & Sheep (Ovis aries) & ÇBT III & -19.3 & 6.5 & 3.2 & 14.2 & 39.6 \\
\hline 3251 & Sheep (Ovis aries) & ÇBT II & -18.5 & 5.7 & 3.2 & 13.0 & 35.8 \\
\hline 3253 & Sheep (Ovis aries) & FPEU & -19.6 & 6.0 & 3.2 & 13.9 & 38.5 \\
\hline 2203 & Pig $(S u s)$ & ÇBT III & -19.0 & 7.3 & 3.2 & 13.1 & 35.8 \\
\hline 2651 & Pig $(S u s)$ & SPEU & -20.1 & 5.5 & 3.2 & 9.8 & 27.4 \\
\hline 2652 & Pig $(S u s)$ & ÇBT III & -19.5 & 7.1 & 3.2 & 13.7 & 37.8 \\
\hline 2653 & Pig (Sus) & ÇBT I & -19.9 & 5.6 & 3.4 & 4.5 & 12.9 \\
\hline 2655 & Pig (Sus) & ÇBT II & -18.7 & 4.7 & 3.3 & 8.5 & 24.0 \\
\hline 2657 & Pig (Sus) & ÇBT II & -19.2 & 7.3 & 3.2 & 11.8 & 32.9 \\
\hline 2658 & Pig (Sus) & ÇBT IV & -18.9 & 5.9 & 3.3 & 10.2 & 29.0 \\
\hline 2659 & Pig $(S u s)$ & ÇBT II & -19.4 & 6.6 & 3.3 & 9.7 & 27.1 \\
\hline 2661 & Pig (Sus) & FPEU & -19.8 & 8.0 & 3.2 & 9.7 & 26.9 \\
\hline 2662 & Pig $(S u s)$ & ÇBT IV & -19.8 & 6.7 & 3.3 & 10.9 & 30.9 \\
\hline 2663 & Pig (Sus) & ÇBT III & -20.2 & 5.7 & 3.4 & 7.3 & 21.2 \\
\hline 2664 & Pig (Sus) & SPEU & -20.0 & 6.5 & 3.3 & 8.9 & 25.3 \\
\hline 2666 & Pig $(S u s)$ & ÇBT IV & -18.7 & 6.0 & 3.3 & 8.7 & 24.8 \\
\hline 2667 & Pig (Sus) & ÇBT II & -19.4 & 6.4 & 3.3 & 12.6 & 35.5 \\
\hline 2668 & Pig (Sus) & FPEU & -19.7 & 7.6 & 3.5 & 4.0 & 12.0 \\
\hline 2669 & Pig (Sus) & ÇBT IV & -20.3 & 6.7 & 3.3 & 10.4 & 29.2 \\
\hline 2926 & Pig (Sus) & ÇBT I & -19.1 & 6.0 & 3.2 & 13.2 & 36.2 \\
\hline 2927 & Pig (Sus) & ÇBT IV & -19.6 & 7.2 & 3.2 & 15.4 & 42.1 \\
\hline 2928 & Pig $(S u s)$ & ÇBT I & -19.4 & 6.3 & 3.2 & 13.5 & 37.1 \\
\hline 3015 & Pig (Sus) & ÇBT I & -19.0 & 6.7 & 3.2 & 14.1 & 39.1 \\
\hline
\end{tabular}


Table 2 (continued)

\begin{tabular}{|c|c|c|c|c|c|c|c|}
\hline $\begin{array}{l}\text { Sample ID } \\
\text { (GUsi) }\end{array}$ & Species & Phase & $\delta^{13} \mathrm{C}$ & $\delta^{15} \mathrm{~N}$ & $\mathrm{C} / \mathrm{N}$ & $\% \mathrm{~N}$ & $\% \mathrm{C}$ \\
\hline 3016 & Pig $(S u s)$ & SPEU & -19.4 & 7.1 & 3.2 & 13.4 & 37.1 \\
\hline 3088 & Pig (Sus) & ÇBT IV & -19.5 & 6.9 & 3.2 & 9.4 & 26.1 \\
\hline 3122 & Pig $(S u s)$ & ÇBT I & -19.6 & 6.6 & 3.3 & 9.0 & 25.3 \\
\hline 3123 & Pig (Sus) & ÇBT III & -19.4 & 6.9 & 3.3 & 9.6 & 27.4 \\
\hline 3124 & Pig (Sus) & ÇBT III & -19.3 & 7.0 & 3.3 & 9.8 & 27.5 \\
\hline 3125 & Pig (Sus) & ÇBT III & -20.3 & 6.7 & 3.3 & 13.5 & 38.0 \\
\hline 3126 & Pig (Sus) & ÇBT II & -19.8 & 6.2 & 3.3 & 9.6 & 27.0 \\
\hline 3127 & Pig (Sus) & ÇBT I & -19.6 & 7.7 & 3.2 & 12.9 & 35.6 \\
\hline 3128 & Pig (Sus) & ÇBT III & -19.5 & 7.6 & 3.3 & 14.0 & 39.2 \\
\hline 3129 & Pig (Sus) & ÇBT II & -19.4 & 6.5 & 3.2 & 12.1 & 33.7 \\
\hline 3130 & Pig (Sus) & SPEU & -19.0 & 8.2 & 3.3 & 12.4 & 34.7 \\
\hline 3131 & Pig $(S u s)$ & ÇBT I & -19.3 & 6.1 & 3.3 & 9.8 & 27.4 \\
\hline 3132 & Pig (Sus) & FPEU & -19.0 & 6.8 & 3.3 & 12.5 & 35.2 \\
\hline 3133 & Pig $(S u s)$ & ÇBT III & -19.2 & 7.8 & 3.4 & 5.6 & 16.4 \\
\hline 3134 & Pig $(S u s)$ & ÇBT II & -19.3 & 7.0 & 3.2 & 11.6 & 32.2 \\
\hline 3139 & Pig $(S u s)$ & ÇBT III & -20.3 & 6.4 & 3.3 & 10.5 & 29.6 \\
\hline 3148 & Pig $(S u s)$ & SPEU & -19.1 & 7.3 & 3.2 & 8.7 & 24.3 \\
\hline 3150 & Pig $(S u s)$ & ÇBT III & -19.0 & 6.0 & 3.2 & 11.8 & 32.8 \\
\hline 3151 & Pig $(S u s)$ & ÇBT III & -19.0 & 6.6 & 3.2 & 12.6 & 35.1 \\
\hline 3152 & Pig (Sus) & ÇBT III & -19.0 & 7.1 & 3.2 & 13.0 & 36.1 \\
\hline 3153 & Pig $(S u s)$ & ÇBT I & -19.5 & 6.0 & 3.2 & 13.4 & 36.9 \\
\hline 3159 & Pig $(S u s)$ & FPEU & -18.3 & 5.4 & 3.2 & 8.8 & 24.4 \\
\hline 3160 & Pig $(S u s)$ & FPEU & -19.5 & 7.6 & 3.2 & 12.0 & 32.8 \\
\hline 3162 & Pig $(S u s)$ & ÇBT III & -19.3 & 6.6 & 3.2 & 12.6 & 35.0 \\
\hline 3165 & Pig $(S u s)$ & ÇBT III & -19.0 & 7.3 & 3.3 & 10.0 & 28.0 \\
\hline 3166 & Pig (Sus) & ÇBT I & -18.6 & 6.0 & 3.2 & 18.3 & 50.7 \\
\hline 3167 & Pig (Sus) & ÇBT I & -18.8 & 6.4 & 3.2 & 13.0 & 35.9 \\
\hline 3242 & Pig (Sus) & ÇBT II & -19.2 & 6.7 & 3.2 & 13.5 & 37.4 \\
\hline 3243 & Pig (Sus) & ÇBT II/III & -19.4 & 7.3 & 3.3 & 13.8 & 38.6 \\
\hline 3245 & Pig (Sus) & FPEU & -19.1 & 7.8 & 3.2 & 11.3 & 31.1 \\
\hline 3249 & Pig $(S u s)$ & ÇBT III & -19.4 & 7.1 & 3.2 & 10.0 & 27.8 \\
\hline 3246 & Pig (Sus) & ÇBT II & -19.9 & 6.6 & 3.3 & 13.2 & 36.8 \\
\hline 3247 & Pig $(S u s)$ & ÇBT III & -19.9 & 7.0 & 3.2 & 12.0 & 33.3 \\
\hline 3248 & Pig $(S u s)$ & FPEU & -19.4 & 6.0 & 3.3 & 12.3 & 34.5 \\
\hline 2206 & Dog (Canis familiaris) & ÇBT I & -19.4 & 6.2 & 3.1 & 12.6 & 34.0 \\
\hline 3109 & Dog (Canis familiaris) & ÇBT III & -19.0 & 7.7 & 3.2 & 12.7 & 35.1 \\
\hline 3110 & Dog (Canis familiaris) & ÇBT I & -18.9 & 8.3 & 3.2 & 12.4 & 34.2 \\
\hline 3111 & Dog (Canis familiaris) & ÇBT I & -19.3 & 6.1 & 3.3 & 11.0 & 30.9 \\
\hline 3112 & Dog (Canis familiaris) & ÇBT II & -18.9 & 6.9 & 3.2 & 13.5 & 37.4 \\
\hline 3113 & Dog (Canis familiaris) & FPEU & -18.6 & 9.8 & 3.3 & 11.3 & 32.2 \\
\hline 3121 & Dog (Canis familiaris) & ÇBT II & -18.9 & 7.2 & 3.2 & 10.9 & 30.4 \\
\hline 3146 & Dog (Canis familiaris) & ÇBT III & -19.4 & 6.5 & 3.3 & 8.3 & 23.3 \\
\hline
\end{tabular}

$\delta^{15} \mathrm{~N}=6.4 \pm 0.6 \%$ o $(n=23)$; goat average $\delta^{13} \mathrm{C}=-19.3 \pm 0.8 \%$ o and $\delta^{15} \mathrm{~N}=5.8 \pm 0.8 \%$ o $\left.(n=4)\right)$.

The pigs sampled were identified as domestic based on their small phenotypic size in comparison to the wild progenitor and on the fact that other hunted animals were a very small component of the faunal assemblage (Bartosiewicz and Gillis 2011; Bartosiewicz et al. 2013, 111, Figs. 7 and 8). One of the pigs sampled, GUsi-2663, is a sub-adult specimen. However, the $\delta^{13} \mathrm{C}$ and $\delta^{15} \mathrm{~N}$ values of this specimen overlap those obtained for the adults, i.e. no suckling enrichment effect is 
evident by this age. This specimen is therefore considered along with the adults. Pig mean $\delta^{13} \mathrm{C}$ and $\delta^{15} \mathrm{~N}$ values suggest a relatively uniform diet, with average $\delta^{13} \mathrm{C}$ and $\delta^{15} \mathrm{~N}$ of $-19.3 \pm 0.4$ and $6.8 \pm 0.6 \%$ o $(n=54)$, respectively.

By comparison, cattle $\delta^{13} \mathrm{C}$ and $\delta^{15} \mathrm{~N}$ values are more variable, with a relatively large range in both isotope values evident (see Table 2 and Fig. 4). The average values with standard deviation are $\delta^{13} \mathrm{C}=-18.7 \pm 0.9 \%$ and $\delta^{15} \mathrm{~N}=7.1 \pm 1.1 \%$ $(n=40)$. The range of cattle $\delta^{15} \mathrm{~N}$ values is wide, spanning $4.3 \%$ with a minimum value of $5.5 \%$ and a maximum value of $9.8 \%$. The range of cattle $\delta^{13} \mathrm{C}$ values is also broad, from -20.1 to $-17.0 \%$ o. The variation in cattle stable isotope values does not correspond to diachronic change (there are no statistically significant differences in the $\delta^{13} \mathrm{C}$ and $\delta^{15} \mathrm{~N}$ values between bones associated with various phases of activity at Çamlıbel Tarlası).

\section{Statistical evaluation of domesticate herbivore stable isotope values}

Bartlett's test was used to assess the null hypothesis that the variance of the $\delta^{13} \mathrm{C}$ values of the domesticates (cattle, caprine and pig) is homogenous. The variance of the domesticate $\delta^{13} \mathrm{C}$ values was found to be significantly different (Bartlett $\chi^{2}=25.582$ with probability $0.000003, \chi^{2}$ value for significance at $5 \%$ and $d . f .2$ is $>5.991$ ). Figure 5 shows the distribution of $\delta^{13} \mathrm{C}$ values by taxon. The non-parametric Kruskal-Wallis test was used to assess the null hypothesis that the $\delta^{13} \mathrm{C}$ values of the domesticates were uniform. The $\delta^{13} \mathrm{C}$ values were found to be statistically different $(K=12.466179, p=0.001963)$. The same statistical tests were undertaken for the domesticates with the exclusion of goats (owing to small sample size) and the caprines that could not be identified to species level. Bartlett's test indicated that the variance of the domesticate $\delta^{13} \mathrm{C}$ values (i.e. cattle, pig and sheep) remained significantly different (Bartlett $\chi^{2}=24.763$ with probability $0.000004, \chi^{2}$ value for significance at $5 \%$ and d.f. 2 is $>5.991$ ). The Kruskal-Wallis test also indicated that there is a statistically significant difference in the $\delta^{13} \mathrm{C}$ values of the different domesticates $(K=12.938133$, $p=0.001551$, for cattle, caprine and pig; $K=12.466179$, $p=0.0001963$, for cattle, sheep and pig).

The same sets of statistical analyses were repeated to compare the $\delta^{15} \mathrm{~N}$ values of the domestic herbivores. The variances of the $\delta^{15} \mathrm{~N}$ values were found to be unequal (Bartlett $\chi^{2}=9.957$ with probability $0.002069, \chi^{2}$ value for significance at $5 \%$ and d.f. 2 is $>5.991$, for cattle, caprines and pig; Bartlett $\chi^{2}=12.362$ with probability 0.006885 , for cattle, sheep and pig) - see Fig. 6 for distribution of $\delta^{15} \mathrm{~N}$ values. The $\delta^{15} \mathrm{~N}$ values of the domesticates are significantly different (Kruskal-Wallis test- $K=10.135896, p=0.006295$, for cattle, caprines and pig; $K=9.423774, p=0.008988$, for cattle, sheep and pig).

A post hoc Mann-Whitney $U$ test was used to examine pairwise differences in stable isotope values. Increased
Fig. 4 Scatterplot of average $\delta^{13} \mathrm{C}$ and $\delta^{15} \mathrm{~N}$ values of Çamlıbel Tarlası domesticate samples by species with standard deviation indicated by error bars. The average $\delta^{13} \mathrm{C}$ and $\delta^{15} \mathrm{~N}$ values of the adult humans from Çamlıbel Tarlası have been included for comparison

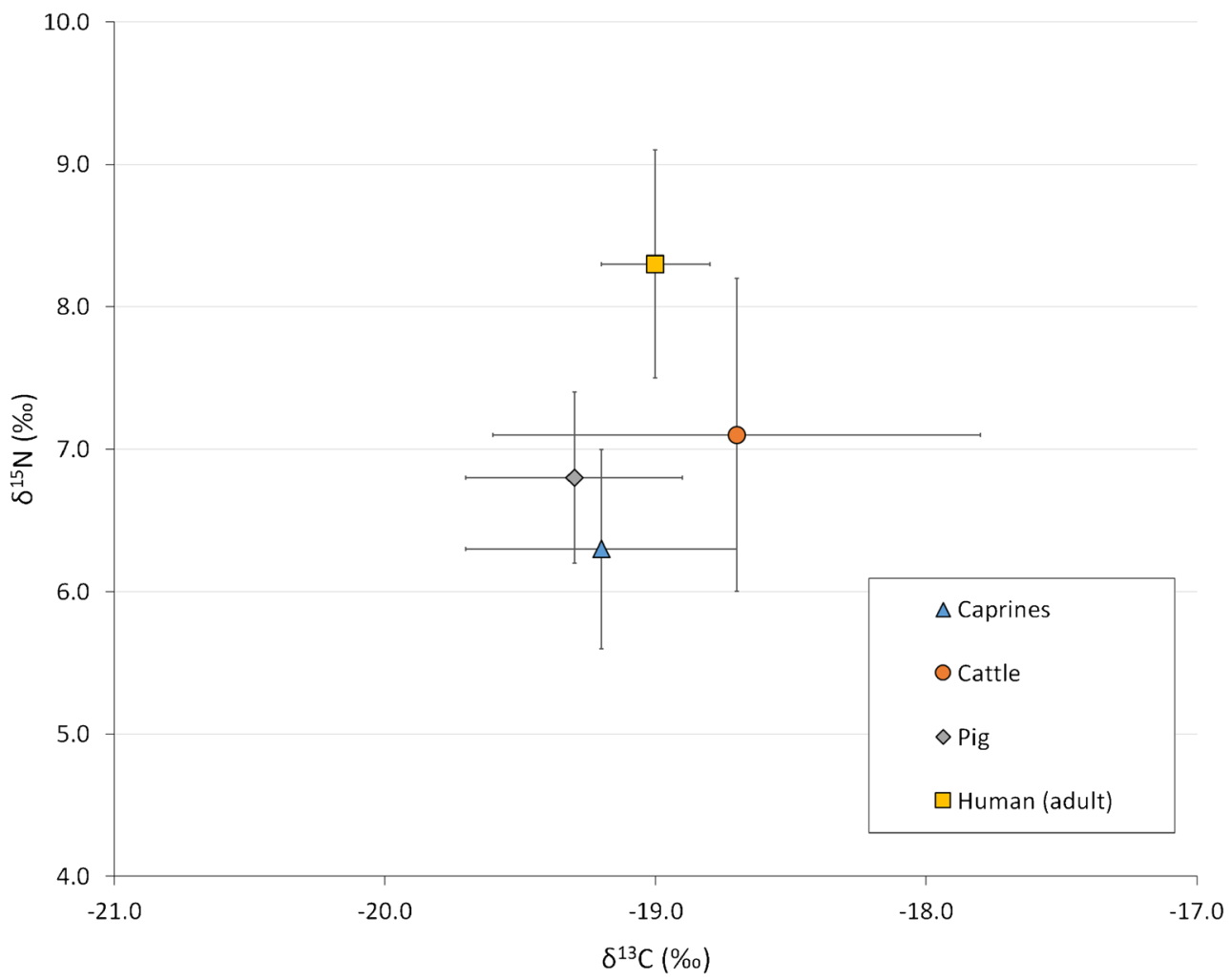




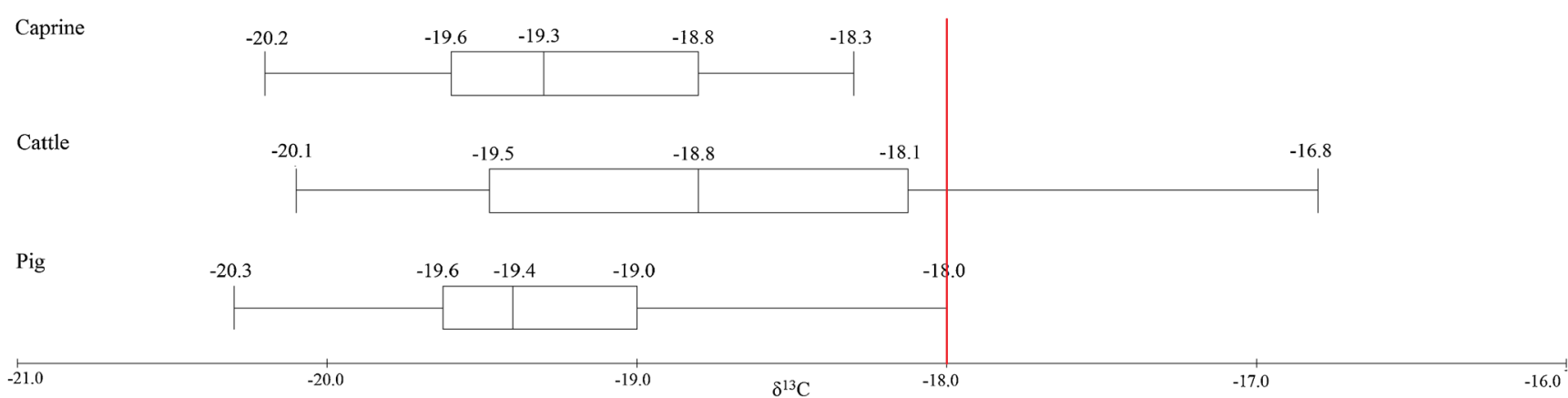

Fig. 5 Boxplot showing the distribution of $\delta^{13} \mathrm{C}$ values of the domesticates from Çamlibel Tarlası by taxon. The red line highlights the $\delta^{13} \mathrm{C}$ value $-18.0 \%$, which has been used as a 'threshold' value for the consumption of C4 resources (e.g. Pearson et al. 2007)

stringency was employed to compensate for multiple testing ( $p$ has significance at $\leq 0.05 / 3$, i.e. 0.0167 ). The $p$ values of the Mann-Whitney $U$ test and a summary of statistical significance are presented in Tables 3, 4 and 5. Figure 7 provides a graphical representation of the isotopic relationships of the cattle, caprines and pigs for both carbon and nitrogen values based on the Mann-Whitney results.

\section{Discussion}

\section{Domesticate forage and animal keeping at Çamlıbel Tarlası}

Statistical analysis of the carbon and nitrogen stable isotope values of the domesticates has demonstrated that the cattle have distinctive stable isotope values from both the pigs and the caprines at Çamlıbel Tarlası. There are several possible diet-related explanations that may account for these differences including (i) differences in foddering practices, (ii) differences in foraging behaviour and (iii) differences in areas grazed.

Domesticate animals often have multiple uses and may be fed distinctive diets depending on function (Bayer et al. 2003). For example, in traditional small-scale farming economies, cattle kept principally for milk may be non-grazed, fed exclusively on fodder crops to ensure high quality diet to maximise productivity (van Shaik et al. 1996). At Late Neolithic/Early
Chalcolithic Ilıpınar, barley kernels and chaff were recovered in the dung of stalled cattle, interpreted by Cappers (2008, p. 120 ) as a diet specific to 'beasts that are used for ploughing' (Cappers 2008, p. 120). Although the energy requirements of non-female draught cattle have been demonstrated to be similar to that of non-draught bulls (Goe and McDowell 1980), cows used for traction show reduced fertility and milk production partially mitigated if nutritionally high quality feed is provided (Jabbar 1993). The majority of the identified cattle remains were those of mature animals, a mortality profile consistent with use for traction or dairy (Bartosiewicz and Gillis 2011). There is no archaeological evidence to support confined stalling or selective foddering of cattle at Camlıbel Tarlası. However, the most recent settlement at Camlıbel Tarlası was surrounded by a boundary wall, a relatively weak construction which was clearly not defensive in character. Such a wall would have been extremely useful for the protection of livestock in an environment which was potentially home to a range of large predators such as leopards, lions, bears and wolves - the latter still present today.

Domesticates have distinct ingestive and digestive capabilities (Prache et al. 1998) resulting in different behaviours in free-foraging animals. Pigs, as facultative omnivores, might be anticipated to have a distinctive diet from the domesticated ruminants. The diets of domestic pigs vary depending on husbandry practices. Pig farmers traditionally practice one of three feeding strategies, (i) free roaming and foraging; (ii) grazing in fields often with other livestock; and (iii) penning,

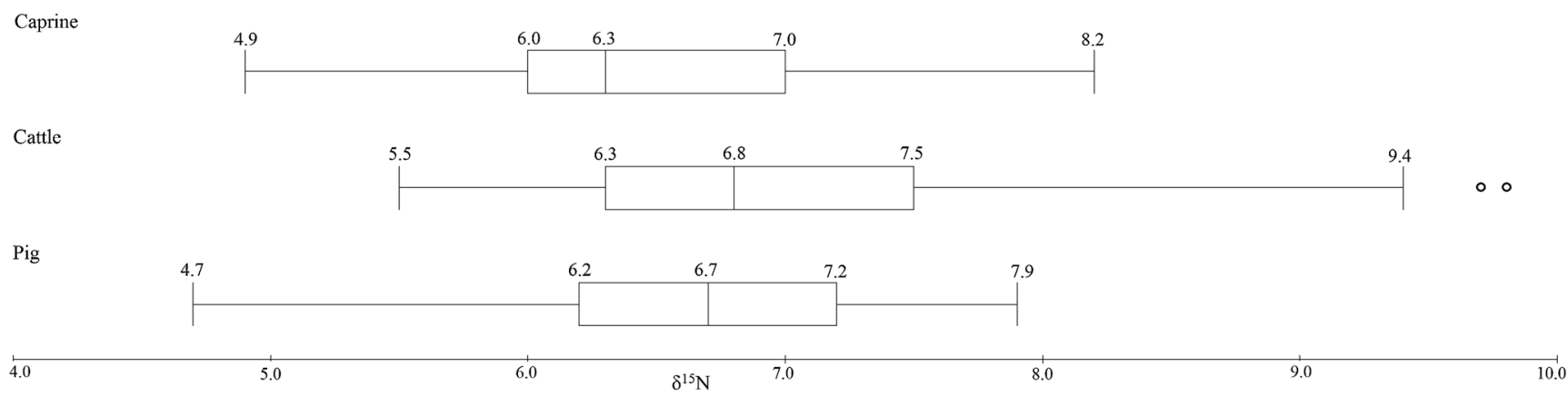

Fig. 6 Boxplot showing the distribution of $\delta^{15} \mathrm{~N}$ values of the domesticates from Çamlıbel Tarlası by taxon. Two cattle have statistically outlying $\delta^{15} \mathrm{~N}$ values 
Table 3 Mann-Whitney $U$ test $p$ values of pairwise comparison of domesticate $\delta^{13} \mathrm{C}$ values

\begin{tabular}{llll}
\hline$\delta^{13} \mathrm{C}$ & Cattle & Caprines & Pig \\
\hline Cattle & & & \\
Caprines & $p=0.032544$ & & \\
Pig & $p=0.000630$ & $p=0.138028$ & \\
Sheep & $p=0.139705$ & $p=0.466061$ & $p=0.039171$ \\
\hline
\end{tabular}

i.e. confined to spaces such as pig sties. Free roaming pigs tend to forage over large areas and while they consume a wide range of animal foods including insects, eggs, small mammals and carrion, they are predominantly herbivorous (Studnitz et al. 2007). Penned pigs will generally be fed on plants and on domestic/household waste. If the waste products include animal proteins (e.g. milk and meat or even faeces) resulting pig $\delta^{15} \mathrm{~N}$ values will be higher than those of free roaming or field grazed animals. However, as indicated above, the $\delta^{13} \mathrm{C}$ and $\delta^{15} \mathrm{~N}$ values of the pigs at Çamlıbel Tarlası are statistically equivalent to those of the sheep as well as the extended group that includes all caprines (i.e. obligate herbivores), suggesting that the pigs were unlikely to have been fed on domestic refuse often rich in animal proteins.

Cattle and sheep, despite both being grazing ruminants, may also have distinctive foraging behaviours. Sheep tend to target higher quality forage owing to reduced gut size and shorter digestion times as well as being able to be more selective in forage owing to the shape and reduced size of the ovine dental arcade (Prache et al. 1998). Cattle tolerate lower quality and rougher forage more readily than sheep (Prache et al. 1998).

Local vegetation heterogeneity accompanied by different foraging behaviours could potentially account for the differences evident in the isotope values of cattle and sheep at Çamlıbel Tarlası. Given the range of the cattle $\delta^{13} \mathrm{C}$ values at Camlıbel Tarlası, from -20.1 up to $-17.0 \%$, it could be argued (cf. Pearson et al. 2007; Budd et al. 2013) that the source of this heterogeneity is the inclusion (or greater inclusion) of $\mathrm{C}_{4}$ plants in cattle diet. However, all of the crop and wild grass species identified at Camlıbel Tarlası use the $\mathrm{C}_{3}$ photosynthetic pathway (Papadopoulou and Bogaard 2012, Table 4). Two plants recovered were not identifiable to species

Table 4 Mann-Whitney $U$ test $p$ values of pairwise comparison of domesticate $\delta^{15} \mathrm{~N}$ values

\begin{tabular}{llll}
\hline$\delta^{15} \mathrm{~N}$ & Cattle & Caprines & Pig \\
\hline Cattle & & & \\
Caprines & $p=0.003240$ & & \\
Pig & $p=0.232884$ & $p=0.025863$ & \\
Sheep & $p=0.004600$ & $p=0.743375$ & $p=0.022187$ \\
\hline
\end{tabular}

Table 5 Summary of statistical significance of differences in $\delta^{13} \mathrm{C}$ and $\delta^{15} \mathrm{~N}$ values of domesticates

\begin{tabular}{|c|c|c|c|c|c|c|}
\hline & \multicolumn{3}{|l|}{$\delta^{13} \mathrm{C}$} & \multicolumn{3}{|l|}{$\delta^{15} \mathrm{~N}$} \\
\hline & Cattle & Caprines & Pig & Cattle & Caprines & Pig \\
\hline \multicolumn{7}{|l|}{ Cattle } \\
\hline Caprines & No & & & Yes & & \\
\hline Pig & Yes & No & & No & No & \\
\hline Sheep & No & No & No & Yes & No & \\
\hline
\end{tabular}

level, one from the borage (Boraginacaea) or sedge (Cyperaceae) families and the other from the saltbush genus (Atriplex sp.). These families include both $\mathrm{C}_{3}$ and $\mathrm{C}_{4}$ species (Edwards and Walker 1983). However, the presence of these broad taxa does not convincingly indicate the presence of $\mathrm{C}_{4}$ plant species in the Çamlibel Tarlası locale. Furthermore, it is unlikely that $\mathrm{C}_{4}$ cereal crops such as millet (Panicum miliaceum) were available to the inhabitants of Camlıbel Tarlasi. Millet was not cultivated in central Anatolia in large quantities before at least the Bronze Age and possibly later (e.g. Nesbitt and Summers 1988; Riehl and Nesbitt 2003).

An alternative scenario to heterogeneity in local plant forage is the movement of domestic livestock between different pastures, potentially some distance from settlements and possibly with access to isotopically distinct plants (cf. Peters et al. 2013). Although $C_{3}$ plants have dominated Anatolian vegetation throughout the Holocene (Rao et al. 2012), $\mathrm{C}_{4}$ plants were certainly present at least regionally. Consumption of $\mathrm{C}_{4}$ plants is clearly indicated by the range of $\delta^{13} \mathrm{C}$ values of wild cattle (Bos spp.) and the plant remains at the Aceramic Neolithic site of Aşıklı Höyük in the Cappadocian region of Turkey (Pearson et al. 2007). $\mathrm{C}_{4}$ plants have also been recovered from a number of sites in Anatolia and in some cases were evidently

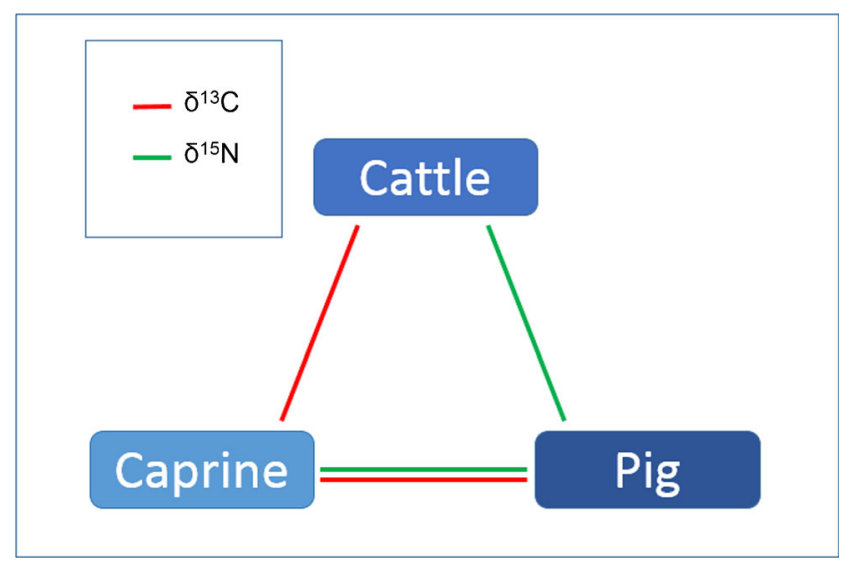

Fig. 7 Graphical representation of statistical significance based on Mann-Whitney $U$ test with increase stringency. Lines between the groups represent statistically indistinguishable isotope values. Statistical equivalence of $\delta^{15} \mathrm{~N}$ values is indicated by the green line, while that of $\delta^{13} \mathrm{C}$ is indicated by the red line 
consumed by livestock. For example, at Çatalhöyük, located in south-central Anatolia, $\mathrm{C}_{4}$ grasses Aeluropus, Crypsis and Sporobolus, as well as Eleocharis (generally a $\mathrm{C}_{4}$ plant although Bruhl and Wilson (2007) describe $\mathrm{C}_{3} / \mathrm{C}_{4}$ intermediate and variant species), were recovered from animal dung (Richards et al. 2003; Bogaard et al. 2013a). The $\mathrm{C}_{4}$ ruderal, sun spurge (Euphorbia helioscopia), is present at Late Neolithic/Early Chalcolithic Ilıpınar, in North West Anatolia, but is not abundant (Cappers 2008).

A further possibility cannot be ruled out, that is the external, and possibly long-distance, provisioning of smaller settlements such as Çamlıbel Tarlası with at least some of their livestock or meat. Arbuckle (2012) noted increasing complexity in the management of sheep herds throughout the Chalcolithic in central Anatolia, which were at least in part distributed to settlements by specialist mobile pastoralists. Concrete evidence for far-reaching trade contacts at Çamlıbel Tarlası include finds of cockle shells (Cardiidae), which must have originated from either the Black Sea or the Mediterranean, obsidian from Cappadocia, flint blades from unknown exotic sources and a casting mould for ring-shaped figurines indicating an ideological link to the Southern Balkans (Schoop 2011; Schoop and Lehner 2013). Livestock may thus have been imported in the form of exchange or at social occasions when groups living in the broader area congregated. Meanwhile, locals may have kept small stocks. That cattle meat may have been consumed only occasionally, possibly during social gatherings or 'feasts', is supported indirectly by the average nitrogen stable isotope value of the inhabitants of Çamlıbel Tarlası (Pickard et al. 2016), which is similar to that of the cattle, suggesting that cattle meat was unlikely to be a significant or consistent source of dietary protein.

\section{Domesticate forage and animal keeping across prehistoric Anatolia}

The results from Çamlıbel Tarlası add to a small but growing body of isotope data from domesticates at Neolithic and Chalcolithic sites across prehistoric Anatolia.

At Çamlıbel Tarlası, the relatively low $\delta^{15} \mathrm{~N}$ values of the pigs in comparison to ruminants suggest that they were likely free roaming and foraging. Pearson et al. (2015) also noted that the relatively low average $\delta^{15} \mathrm{~N}$ value of pig in comparison to the human inhabitants and domesticates of Neolithic Çatalhöyük suggested that these animals were not fed on domestic waste (although three outliers with comparatively high $\delta^{15} \mathrm{~N}$ values may be an exception). By contrast, at the PPNB site of Nevalı Çori in southeast Turkey, domestic pig and humans have similar $\delta^{15} \mathrm{~N}$ mean values $(5.5 \pm 1.9$ and $6.1 \pm 1.0 \%$, respectively) and ranges (3.9 to $8.2 \%$ and 4.4 to $8.8 \%$, respectively) implying similar diets, i.e. at Nevalı Çori, the pigs were likely fed on household waste and thus possibly penned (Lösch et al. 2006). However, only four pig specimens were analysed at this site.

The wide ranges of $\delta^{13} \mathrm{C}$ and $\delta^{15} \mathrm{~N}$ values of sheep and cattle from Çatalhöyük were attributed by Pearson et al. $(2007,2015)$ to the grazing of herds in different areas - in pastures with only $\mathrm{C}_{3}$ species, as well as those with both $\mathrm{C}_{3}$ and $\mathrm{C}_{4}$ plants. Extra-local grazing of at least some cattle is paralleled at Çamlıbel Tarlası. By contrast, the sheep from Çamlıbel Tarlası have relatively homogeneous $\delta^{13} \mathrm{C}$ and $\delta^{15} \mathrm{~N}$ values. The differences in sheep forage and by implication stock-keeping practices between Çatalhöyük and Çamlibel Tarlası may reflect the distinctive nature of the two sites. The scale of Çatalhöyük, a large agglomerated village or proto-urban site spanning c. $130,000 \mathrm{~m}^{2}$ (Hodder and Cessford 2004), likely necessitated extra-household herding strategies and grazing in various pastures potentially at some distance from the site (Pearson et al. 2015). In contrast, Çamlıbel Tarlası was a small-scale rural settlement covering an area of no more than $250 \mathrm{~m}^{2}$ - small herds of sheep were likely managed locally.

A trend of ${ }^{15} \mathrm{~N}$ enrichment is evident in the sheep from later levels at Çatalhöyük. Budd et al. (2013) also noted an increase in $\delta^{13} \mathrm{C}$ and $\delta^{15} \mathrm{~N}$ values of animal remains $(n=9)$ from Neolithic to Early Chalcolithic contexts at Aktopraklık, Northwest Anatolia. As both Pearson et al. (2015) and Budd et al. (2013) indicated, one possible explanation for ${ }^{15} \mathrm{~N}$ enrichment is the grazing of animals on manured fields (e.g. Fraser et al. 2011; Bogaard et al. 2013b; Styring et al. 2014). Crop manuring has been demonstrated at early Neolithic sites in southeastern Europe from c. 5900 BC (Bogaard et al. 2013b). At Çamlıbel Tarlası, the average $\delta^{15} \mathrm{~N}$ value of all the domesticates is $6.7 \%$. Assuming a diet-herbivore offset of $4 \%$, the average $\delta^{15} \mathrm{~N}$ value of the domesticate forage at Çamlıbel Tarlası was $2.7 \%$; this relatively low forage $\delta^{15} \mathrm{~N}$ value suggests that these animals were not fed on manured crops/stubble (cf. Bogaard et al. 2013b). However, identifying manuring practices and/or animal penning from the stable isotope values of domesticates is non-trivial. In part, this is a consequence of the temporal and spatial variability in soil $\delta^{15} \mathrm{~N}$ values (e.g. Ambrose 1991). Also problematic is the inclusion of ${ }^{15} \mathrm{~N}$-depleted pulse crops in domesticate diet, which may mask the effects of consuming manured cereals or stubble. Moreover, ${ }^{15} \mathrm{~N}$ enrichment of pulse crops is evident only with intensive and protracted manuring (Fraser et al. 2011; Bogaard et al. 2013b). Pulses including bitter vetch and lentil were identified at Çamlıbel Tarlası and may have comprised a significant part of human (see Pickard et al. 2016) and/or domesticate diet.

The comparative analysis of the domesticate stable isotope datasets presented above is offered cautiously because of (i) spatial and temporal variations in environmental $\delta^{13} \mathrm{C}$ and $\delta^{15} \mathrm{~N}$ values (e.g. Schwarcz et al. 1999; van Klinken et al. 1994; van Klinken et al. 2000) and the broad geographical 
range and chronological span of sites with stable isotope datasets in prehistoric Anatolia, (ii) the difficulty of distinguishing early domesticates from wild progenitors from morphological characteristics at Early Neolithic sites (see Zeder et al. (2006) for summary), (iii) the small datasets available from some sites and (iv) the complexities of identifying the consumption of pulses.

\section{Conclusion}

Carbon and nitrogen stable isotope analyses indicate that the domesticates from Çamlıbel Tarlası had diets based mainly on $\mathrm{C}_{3}$ resources. Of all the domesticates at Çamlıbel Tarlası, cattle exhibit the widest range of $\delta^{13} \mathrm{C}$ and $\delta^{15} \mathrm{~N}$ values. Moreover, cattle have statistically distinct isotope values from both the sheep/caprines, and the pigs recovered from the site. This indicates that the cattle had distinctive foraging behaviour not only from that of the pigs (which is perhaps not surprising) but also from that of the sheep. The $\delta^{13} \mathrm{C}$ values of the cattle hint at the inclusion of $\mathrm{C}_{4}$ plants in diet. However, no $\mathrm{C}_{4}$ plants were identified in the plant macro assemblage recovered at the site and this suggests (if indeed $\mathrm{C}_{4}$ plants were included in the diet of cattle) that they were grazing in nonlocal pastures. The inter-species variability in isotope values points to distinctive and potentially complex foraging and/or feeding behaviours at Late Chalcolithic Çamlıbel Tarlası.

\begin{abstract}
Acknowledgments This research was supported by the British Academy/Leverhulme Small Research Grants (SG121910) and the School of History, Classics and Archaeology, University of Edinburgh. The excavations at Çamlıbel Tarlası were conducted as a collaborative project by the University of Edinburgh and the German Archaeological Institute. Thanks are extended to Professor Gordon Cook (SUERC). We are also grateful to Juliet Voon, Samantha Williamson, Lisa Bird and Caroline Hall-Eastman who helped select and prepare the samples for analysis.
\end{abstract}

Open Access This article is distributed under the terms of the Creative Commons Attribution 4.0 International License (http:// creativecommons.org/licenses/by/4.0/), which permits unrestricted use, distribution, and reproduction in any medium, provided you give appropriate credit to the original author(s) and the source, provide a link to the Creative Commons license, and indicate if changes were made.

\section{References}

Ambrose SH (1990) Preparation and characterisation of bone and tooth collagen for isotopic analysis. J Archaeol Sci 17:431-451. doi:10.1016/0305-4403(90)90007-R

Ambrose SH (1991) Effects of diet, climate and physiology on nitrogen isotope abundances in terrestrial foodwebs. J Archaeol Sci 18:293317

Arbuckle BS (2012) Animals and inequality in Chalcolithic central Anatolia. J Anthropol Archaeol 31:302-313. doi:10.1016/j. jaa.2012.01.008
Bartosiewicz L, Gillis R (2011) Preliminary report on the animal remains from Çamlıbel Tarlası. Archeol Anz 1:76-79

Bartosiewicz L, Gillis R, Girdland-Flink L, Evin A, Cucchi T, Hoelzel R, Vidarsdottir U, Dobney K, Larson G, Schoop U-D (2013) Chalcolithic pig remains from Çamlıbel Tarlası, Central Anatolia. In: De Cupere B, Linseele V, Hamilton-Dyer S (eds) Archaeozoology of the Near East X. Proceedings of the Tenth International Symposium on the Archaeozoology of SouthWestern Asia and adjacent areas. Peeters, Leuven, pp. 101-120

Bayer W, von Lossau A, Feldmann A, (2003) Smallholders and community-based management of farm animal genetic resources. In Community-based management of animal genetic resources. Proceedings of the workshop held in Mbabane, Swaziland May 2001. Food and Agriculture Organization of the United Nations, Rome, 7-11

Bocherens H, Drucker D (2003) Trophic level isotopic enrichment of carbon and nitrogen in bone collagen: case studies from recent and ancient terrestrial ecosystems. Int J Osteoarchaeol 13:46-53. doi:10.1002/oa.662

Bogaard A, Heaton THE, Poulton P, Merbach I (2007) The impact of manuring on nitrogen isotope ratios in cereals: archaeological implications for reconstruction of diet and crop management practices. J Archaeol Sci 34:335-343

Bogaard A, Charles M, Livarda A, Ergun M, Filipovic D, Jones G (2013a) The archaeobotany of mid-later occupation levels at Neolithic Çatalhöyük. In: Hodder I (ed) Humans and landscapes of Çatalhöyük: reports from the 2000-2008 seasons, monographs of the Cotsen Institute of Archaeology. University of California at Los Angeles, Los Angeles, pp. 93-128

Bogaard A, Fraser R, Heaton THE, Wallace M, Vaiglova P, Charles M, Jones G, Evershed RP, Styring AK, Andersen NH, Arbogast R-M, Bartosiewicz L, Gardeisen A, Kanstrup M, Maier U, Marinova E, Ninov L, Schäfer M, Stephan E (2013b) Crop manuring and intensive land management by Europe's first farmers. Proc Natl Acad Sci U S A 110:12589-12594. doi:10.1073/pnas.1305918110

Britton K, Müldner G, Bell M (2008) Stable isotope evidence for saltmarsh grazing in the Bronze Age Severn Estuary, UK: implications for palaeodietary analysis at coastal sites. J Archaeol Sci 35:21112118. doi:10.1016/j.jas.2008.01.012

Brock F, Higham T, Bronk Ramsey C (2010) Pre-screening techniques for identification of samples suitable for radiocarbon dating of poorly preserved bones. J Archaeol Sci 37:855-865. doi:10.1016/j. jas.2009.11.015

Brown TA, Nelson DE, Southon JR (1988) Improved collagen extraction by modified Longin method. Radiocarbon 30:171-177

Bruhl JJ, Wilson KL (2007) Towards a comprehensive survey of $\mathrm{C}_{3}$ and $\mathrm{C}_{4}$ photosynthetic pathways in Cyperacea. Aliso 23:99-148

Budd C, Lillie MC, Alpaslan Roodenberg S, Karul N, Pinhasi R (2013) Stable isotope analysis of Neolithic and Chalcolithic populations from Aktopraklık, northern Anatolia. J Archaeol Sci 40:860-867. doi:10.1016/j.jas.2012.09.011

Cappers R (2008) Plant remains from the Late Neolithic and Early Chalcolithic levels. In: Roodenberg J, Alpaslan Roodenberg S (eds) Life and death in a prehistoric settlement in northwest Anatolia: the Ilıpınar excavations, Volume III. Leiden, Nederlands Instituut voor het Nabije Oosten, pp. 117-148

DeNiro MJ (1985) Postmortem preservation and alteration of in-vivo bone collagen isotope ratios in relation to paleodietary reconstruction. Nature 317:806-809. doi:10.1038/317806a0

DeNiro MJ, Epstein S (1978) Influence of diet on the distribution of carbon isotopes in animals. Geochim Cosmochim Acta 42:495506. doi:10.1016/0016-7037(78)90199-0

DeNiro MJ, Epstein S (1981) Influence of diet on the distribution of nitrogen isotopes in animals. Geochim Cosmochim Acta 45:341351. doi:10.1016/0016-7037(81)90244-1 
Dörfler W, Neef R, Pasternak R (2000) Untersuchungen zur Umweltgeschichte und Agrarökonomie im Einzugsbereich hethitischer Städte. Mitteilungen der Deutschen Orientgesellschaft $132: 367-380$

Düring BS (2008) The early Holocene occupation of north-central Anatolia between 10,000 and 6,000 BC cal: investigating an archaeological terra incognita. Anatol Stud 58:15-46

Edwards G, Walker DA (1983) C3, C4: mechanisms, and cellular and environmental regulation, of photosynthesis. University of California Press, Berkley

Feranec RS (2007) Stable carbon isotope values reveal evidence of resource partitioning among ungulates from modem C-3-dominated ecosystems in North America. Palaeogeogr Palaeoclimatol Palaeoecol 252:575-585

Fraser R, Bogaard A, Heaton T, Charles M, Jones G, Christensen BT, Halstead P, Merbach I, Poulton PR, Sparkes D, Styring AK (2011) Manure and stable isotope ratios in cereals and pulses: towards a new archaeobotanical approach to the inference of land use and dietary practices. J Archaeol Sci 38:2790-2804. doi:10.1016/j. jas.2011.06.024

Fuller BT, Fuller JL, Sage NE, Harris DA, O’Connell TC, Hedges REM (2005) Nitrogen balance and $\delta^{15} \mathrm{~N}$ : why you're not what you eat during pregnancy. Rapid Commun Mass Spectrom 18:2889-2896. doi: $10.1002 / \mathrm{rcm} .170$

Fuller BT, De Cupere B, Marinova E, Van Neer W, Waelkens M, Richards MP (2012) Isotopic reconstruction of human diet and animal husbandry practices during the Classical-Hellenistic, Imperial, and Byzantine periods at Sagalassos, Turkey. Am J Phys Anthropol 149:157-171. doi:10.1002/ajpa.22100

Gerritsen F, Özbal R, Thissen L, Özbal H, Galik A (2010) The Late Chalcolithic settlement of Barcın Höyük. Anatolica 36:197-225

Gillis R, Bréhard S, Balasescu A, Vigne J-D, Popovici D, Balasse M (2013) Sophisticated cattle dairy husbandry at Borduşani-Popină (Romania, 5th mill BC): the evidence from complementary analysis of mortality profiles and stable isotopes. World Archaeology 45: 447-472. doi:10.1080/00438243.2013.820652

Goe MR, McDowell RE (1980) Animal traction: guidelines for utilization. Department of Animal Science Cornell University, Ithaca, New York

Gourichon L, Helmer D (2008) Etude de la faune néolithique de Menteșe (Turquie). In: Roodenberg JJ, Alpaslan Roodenberg S (eds) Life and death in a prehistoric settlement in northwest Anatolia. The Ilıpınar excavations, volume III. Leiden, Nederlands Institut voor het Nabije Oosten, pp. 435-448

Hedges REM, Reynard LM (2007) Nitrogen isotopes and the trophic level of humans in archaeology. J Archaeol Sci 34:1240-1251. doi:10.1016/j.jas.2006.10.015

Hodder I, Cessford C (2004) Daily practice and social memory at Çatalhöyük. Am Antiq 69:17-40. doi:10.2307/4128346

Jabbar MA (1993) Research on cow traction in Africa: some lessons to be learned. In: Lawrence PR, Lawrence K, Dijkman JT, Starkey PH (eds) Recherche pour Le Développement de la traction Animale en Afrique de L'Ouest. Proceedings of the Fourth Workshop of the West Africa Animal Traction Network held in Kano, Nigeria, 913 July 1990. The International Livestock Centre for Africa, Adis Ababa, Ethiopia, pp. 263-268

Jenkins SG, Partridge ST, Stephenson TR, Farley SD, Robbins CT (2001) Nitrogen and carbon isotope fractionation between mothers, neonates and nursing offspring. Oecologia 129:336-341. doi:10.1007 s004420100755

Longin R (1971) New method of collagen extraction for radiocarbon dating. Nature 230:241-242. doi:10.1038/230241a0

Lösch S, Grupe G, Peters J (2006) Stable isotopes and dietary adaptations in human and animals at pre-pottery Neolithic Nevalı Cori, Southeast Anatolia. Am J Phys Anthropol 131:181-193
Marsh B (2010) Geoarchaeology of the landscape at Boğazköy-Hattuša. Archaeol Anz 2010:201-207

Nesbitt M, Summers GD (1988) Some recent discoveries of millet (Panicum miliaceum L. and Setaria italica (L.) P. Beauv.) at excavations in Turkey and Iran. Anatol Stud 38:85-97

Nitsch EK, Humphrey LT, Hedges REM (2010) The effect of parity status on $\delta^{15} \mathrm{~N}$ : looking for the "pregnancy effect" in 18th and nineteenth century London. J Archaeol Sci 37:3191-3199. doi:10.1016/j. jas.2010.07.019

O'Connell TC, Kneale CJ, Tasevska N, Kuhnle GGC (2012) The dietbody offset in human nitrogen isotopic values: a controlled dietary study. Am J Phys Anthropol 149:426-434. doi:10.1002/ajpa.22140

Olsen KC, White CD, Longstaffe FJ, von Heyking K, McGlynn G, Grupe $\mathrm{G}$, Rühli FJ (2014) Intraskeletal isotopic compositions $\left(\delta^{13} \mathrm{C}, \delta^{15} \mathrm{~N}\right)$ of bone collagen: nonpathological and pathological variation. Am J Phys Anthropol 153:598-604. doi:10.1002/ajpa.22459

Özdoğan M (1996) Pre-Bronze Age sequence of Central Anatolia: an alternative approach. In: Magen U, Rashad M (eds) Vom Halys zum Euphrat: Thomas Beran zu Ehren. Ugarit-Verlag, Münster, pp. $185-202$

Papadopoulou I, Bogaard A (2012) A preliminary study of the charred macrobotanical assemblage from Çamlıbel Tarlası, North-Central Anatolia. Archaeol Anz 2011:22-27

Parzinger H (1993) Zur Zeitstellung der Büyükkaya-Ware: Bemerkungen zur vorbronzezeitlichen Kulturfolge Zentralanatoliens. Anatolica 19:211-229

Pearson JA, Buitenhuis H, Hedges REM, Martin L, Russell N, Twiss KC (2007) New light on early caprine herding strategies from isotope analysis: a case study from Neolithic Anatolia. J Archaeol Sci 34: 2170-2179. doi:10.1038/230241a0

Pearson JA, Bogaard A, Charles M, Hillson SW, Larsen CS, Russell N, Twiss K (2015) Stable carbon and nitrogen isotope analysis at Neolithic Çatalhöyük: evidence for human and animal diet and their relationship to households. J Archaeol Sci 57:69-79. doi:10.1016/j. jas.2015.01.007

Peters J, Buitenhuis H, Grupe G, Schmidt K, Pöllath N (2013) The long and winding road: ungulate exploitation and domestication in Early Neolithic Anatolia (10000-7000 cal BC). In: Colledge S, Conolly J, Dobney K, Manning K, Shennan S (eds) Origins and spread of domestic animals in Southwest Asia and Europe. Left Coast Press, Walnut Creek CA, pp. 83-114

Pickard C, Schoop U-D, Dalton A, Sayle KL, Channell I, Calvey K, Thomas J-L, Bartosiewicz L, Bonsall C (2016) Diet at Late Chalcolithic Camlıbel Tarlası, north-central Anatolia: an isotopic perspective. J Archaeol Sci: Reports 5:296-306. doi:10.1016/j. jasrep.2015.11.034

Prache S, Gordon IJ, Rook AJ (1998) Foraging behaviour and diet selection in domestic herbivores. Annales de zootechnie, INRA/EDP. Sciences 47:335-345 <hal-00889735>

Rao ZG, Chen FH, Zhang X, Xu YB, Xue Q, Zhang PY (2012) Spatial and temporal variations of $\mathrm{C}_{3} / \mathrm{C}_{4}$ relative abundance in global terrestrial ecosystem since the Last Glacial and its possible driving mechanism. Chin Sci Bull 57:4024-4035. doi:10.1007/s11434012-5233-9

Richards MP, Pearson J, Molleson TI, Russell N, Martin L (2003) Stable isotope evidence of diet at Neolithic Catalhöyük, Turkey. J Archaeol Sci 30:67-76. doi:10.1006/jasc.2001.0825

Riehl S, Nesbitt M (2003) Crops and cultivation in the Iron Age Near East: change or continuity? In Fischer B, Genz H, Köroğlu JE (eds) Identifying changes: the transition from Bronze to Iron Ages in Anatolia and its neighbouring regions. Proceedings of the International Workshop, 8-9 November Istanbul 2002. Istanbul, Türk Eskiçağ Bilimleri Enstitüsü, pp 301-312.

Sauter F, Puchinger L, Schoop U-D (2003) Fat analysis sheds light on everyday life in prehistoric Anatolia: traces of lipids identified in 
chalcolithic potsherds excavated near Boğazkale, Central Turkey. ARKIVOC XV:15-21

Schoop U-D (2005) Das anatolische Chalkolithikum. Eine chronologische Untersuchung zur vorbronzezeitlichen Kultursequenz im nördlichen Zentralanatolien und den angrenzenden Gebieten. Verlag Bernhard Albert Greiner, Remshalden

Schoop U-D (2010) Ausgrabungen in Çamlıbel Tarlası 2009. Archaeol Anz 2010:191-201

Schoop U-D (2011) Çamlıbel Tarlası, ein metallverarbeitender Fundplatz des vierten Jahrtausends v. Chr. im nördlichen Zentralanatolien. In: Yalçın Ü (ed) Anatolian Metal V. Deutsches Bergbaumuseum, Bochum, pp. 53-68

Schoop U-D (2015) Çamlıbel Tarlası: Late Chalcolithic settlement and economy in the Budaközü Valley (north-central Anatolia). In: Steadman SR, McMahon G (eds) The archaeology of Anatolia I. Recent discoveries (2011-2014). Cambridge Scholars Publishing, Newcastle upon Tyne, pp. 46-68

Schoop U-D, Lehner J (2013) Long-distance trade and communication networks in Late Chalcolithic Anatolia. Heritage Turkey 3:27

Schoop U-D, Grave P, Kealhofer L, Jacobsen G (2009) Radiocarbon dates from Chalcolithic Çamlıbel Tarlası. Archeol Anz 2009:66-67

Schwarcz HP, Dupras T, Fairgrieve SI (1999) ${ }^{15} \mathrm{~N}$ enrichment in the Sahara: in search of a global relationship. J Archaeol Sci 26:629-636

Sealy J, Armstrong R, Schrire C (1995) Beyond lifetime averages: tracing life histories through isotopic analysis of different calcified tissues from archaeological human skeletons. Antiquity 69:290-300

Steadman S (1995) Prehistoric interregional interaction in Anatolia and the Balkans: an overview. Bull Am Sch Oriental Res 299(300):13-32

Studnitz M, Jensen MB, Pedersen LJ (2007) Why do pigs root and in what will they root? A review on the exploratory behaviour of pigs in relation to environmental enrichment. Appl Anim Behav Sci 107: 183-197. doi:10.1016/j.applanim.2006.11.013

Styring AK, Fraser RA, Bogaard A, Evershed RP (2014) The effect of manuring on cereal and pulse amino acid $\delta^{15} \mathrm{~N}$ values. Phytochemistry 102:40-44. doi:10.1016/j.applanim.2006.11.013

Towers J, Jay M, Mainland I, Nehlich O, Montgomery J (2011) A calf for all seasons? The potential of stable isotope analysis to investigate prehistoric husbandry practices. J Archaeol Sci 38:1858-1868. doi:10.1016/j.jas.2011.03.030

van der Merwe NJ, Medina E (1991) The canopy effect, carbon isotope ratios and foodwebs in Amazonia. J Archaeol Sci 18:249-259. doi:10.1016/j.jas.2011.03.030

van Klinken GJ (1999) Bone collagen quality indicator for palaeodietary and radiocarbon measurements. J Archaeol Sci 26:687-695. doi:10.1006/jasc.1998.0385

van Klinken GJ, van der Plicht $\mathrm{H}$, Hedges REM (1994) Bond ${ }^{13} \mathrm{C} /{ }^{12} \mathrm{C}$ ratios reflect (palaeo-) climatic variations. Geophys Res Lett 21: 445-448

van Klinken GJ, Richards MP, Hedges REM (2000) An overview of causes for stable isotopic variations in past European human populations: environmental, ecophysiological, and cultural effects. In: Ambrose SH, Katzenberg MA (eds) Biogeochemical approaches to paleodietary analysis. Springer, New York, pp. 39-63

van Shaik G, Perry BD, Mukhebi AW, Gitau GK, Djikhuizen AA (1996) An economic study of smallholder dairy farms in Murang'a District, Kenya. Prev Vet Med 29:21-36

Zeder MA, Bradley DG, Emshwiller E, Smith BD (2006) Documenting domestication. In: Zeder MA, Emshwiller E, Smith BD, Bradley DG (eds) Archaeological approaches to documenting animal domestication. University of California Press, Berkeley, pp. 1-12 